\title{
The distribution problem of social safety net program in Surabaya and Gresik during pandemic
}

\author{
Imamul Huda Al Shiddiq*, Abdul Kodir, Imam Mukhlis, Febri Kevin Aditya \& Satrya \\ Paramanandana \\ Universitas Negeri Malang, Malang City, Indonesia
}

\begin{abstract}
One of the consequences of the Covid-19 pandemic that is most feared by Indonesia and even developed countries around the world is economic uncertainty. Many economic activities must be temporarily stopped in response to the implementation of efforts to prevent the expansion of Covid-19 infections. Starting from large capital companies to rural MSMEs must close temporarily. This makes various social layers affected economically. Therefore, the government implemented several Social Safety Net (JPS) programs during the pandemic to ease the burden on the affected communities. This study aims to explain the impact of JPS for the economic improvement of vulnerable groups. In addition, this study seeks to explain the level of suitability of field implementation with central government regulations. The method used in this research is a qualitative method by conducting semi-structured interviews with beneficiary communities. The results of this study indicate that the policies set by the central government have not been maximally executed in the regions. There is a difference in the nominal value of obtaining assistance in Sidoarjo municipality compared to the nominal in other cities. An example of a case in the Surabaya city and Gresik municipality was that the recipients of massive aid were mis-targeted. However, most beneficiaries admitted that with this JPS their lives were helped and fulfilled economically.
\end{abstract}

Keywords: Social Safety Network, Poverty, Vulnerable Community, Pandemic, Covid-19

\section{INTRODUCTION}

On March 11, 2020, the World Health Organization (WHO) declared COVID-19 as a global pandemic, taking into account the number of infections that have reached 118,000 cases in more than 110 countries and the continuing risk of global spread (Ducharme 2020). As the case curve increases, each country takes its own initiatives in order to protect their country from this pandemic. More than 80 countries have closed their borders to arrivals from countries with cases of infection, ordered businesses and public spaces to close, social distancing is echoed, and schools are closed (The Economics 2020). The economic impact of the anticipated pandemic, globally, is beyond estimation. The increase in the number of unemployed and poor families is increasing in both developed and developing countries.

Indonesia, as one of the developing countries in Asia, also feels the economic slowdown during the implementation of the national health emergency status. The Minister of Finance revealed that Indonesia's economic growth this year could fall to 2.5\%, even $0 \%$ (Bayu 2020). Millions of families are vulnerable to unemployment and even poverty. As of mid-May 2020, Bappenas has calculated the unemployment rate to reach 2 to 3.7 million people (Hidayat \& Rosana 2020). A projection for the poverty rate due to COVID-19, the lightest, will increase from 9.2 percent in September 2019 (see diagram 1) to 9.7 percent by the end of 2020 or 1.3 million more poor people,

*Corresponding author: imamul.huda.fis@um.ac.id 
the highest projection. severe, the poverty rate will increase to 12.4 percent or 8.5 million more people will become poor (Suryahadi et al. 2020).

As a result, Indonesia needs to implement a social safety net program to assist the new poor in addition to the existing poor. The scope of the definition of a social safety net varies depending on the institution defining it and the scholars researching the topic. The World Bank defines social safety nets as non-contributory assistance aimed at improving the standard of living of poor families or individuals (World Bank n.d.). The International Labor Organization (ILO) defines that social safety nets are anti-poverty assistance provided by the government (Paitoonpong et al. 2008). Meanwhile, the National Development Planning Agency (Bappenas) translates social safety nets as intervention policies to tackle or at least reduce the social impact of the crisis (Kementrian 2014). The basic definition of a social safety net that can be concluded is poverty prevention programs targeted at targets vulnerable to falling into poverty.

In this study, the limitation is taken on the social safety net that applies during the global pandemic COVID-19. It is important to investigate social safety net programs to improve the lives of vulnerable groups during a pandemic as an evaluation and reference for similar policies in the future. Evaluation is urgent given that social safety nets bear the burden of survival for vulnerable audiences. How effective the social safety nets prepared by the government are in supporting the millions of people who do not fall into poverty and those who are already poor do not go hungry needs to be measured. The hope is that if something similar happens in the future, the government is ready to take more effective policies.

\section{METHOD}

This study uses a qualitative method. The data collection process was carried out through interviews with the beneficiary community. The data collection process was carried out in areas with the epicenter of the spread of COVID-19 in East Java, namely Surabaya City and Gresik Regency. Both regions are at the same time the center of industry and business in East Java. So, apart from being affected in terms of public health, the three regions also felt the economic impact due to the implementation of the PSBB. Secondary data is obtained through the process of interpreting data from BPS, the Social Service, related regulations or legislation, and other supporting documents.

The analysis of this research was carried out in three stages. First, data reduction, namely the process of selecting, simplifying data, abstraction, and transforming the crude data obtained in the field. Second, the data presentation stage is a description of information conclusions that allows for drawing conclusions and taking action. Third, is the stage of drawing conclusions and verification.

\section{RESULT AND DISCUSSION}

\subsection{Social assistance in Surabaya}

The distribution of social assistance in Surabaya has a number of problems. Based on field research, it is stated that the social assistance budget has been disbursed by the central government as much as 172.1 trillion which should have been distributed to people affected by the Covid-19 pandemic. The research steps were started from related to social assistance to the Surabaya City Social Service and submitting research permits. The researcher also asks for data on social assistance recipients. However, the recipient data obtained is only based on the number in each subdistrict.

The results of field research through interviews with both respondents and local officials varied considerably. Research in Gunung Anyar Subdistrict has encountered problems even though it has followed licensing procedures related to social assistance research. The research team was not 
allowed to participate in direct interviews. However, the research team received an offer to bring in participants

Another problem is found in Gunung Anyar Tambak Village. Many admissions from kelurahan staff include insufficient human resources and forced data input overnight. This indirectly affects the accuracy of implementing and receiving social assistance. As a solution to this problem, RT and RW have sent people who deserve social assistance. However, this has not yet received a response from the central government

Research in Medayu Village that the RT acknowledges that the data sent is old data. This causes many to receive social assistance but no one. In addition, many are not on target. Apart from the mentioned sub-districts, there is also a respondent's acknowledgment. RR Hartati having her address at Jetis Wetan gang 4 no. 22 is supposed to get thrice. But in reality only once. Respondents have reported to related parties until the field visit on August 4, 2020, but there is still no response from the Surabaya City Social Service.

\subsection{Social assistance in Gresik}

Field research was also carried out in Gresik Regency. There are several findings regarding the distribution of social assistance. The Gresik Regency Social Service is cooperative, and admits that there are problems in the distribution of social assistance to the State Budget. The claim from the agency stated that the delay in some areas was because the village and hamlet had not sent the first stage of the Accountability Report.

In addition, in Abar-abir Village, problems were also found. The village has complained about the large number of gates for the implementation of social assistance distribution. This has resulted in overlapping authority and confusion over aid recipients.

The research team in the field also found that many RT and RW have proposed their residents who were really affected by the economy due to the pandemic. However, what happened was not clear from the Social Service. Meanwhile, the receipt of social assistance in each RT, hamlet and village varied. For example, in Hulaan Hamlet, many residents have received assistance twice. Meanwhile, residents in Gempol Kurung Hamlet still received one-time assistance.

The existing problems cause gaps in the distribution of social assistance. The residents felt that the distribution of social assistance was not well targeted. This is also related to data collection from the Gresik Regency Social Service. Some of the data provided by the department are not in accordance with the facts in the field.

\section{CONCLUSTION}

The Covid-19 pandemic in Indonesia has had an impact not only from the health aspect but also on the socio-economic side. Poverty and unemployment rates have increased due to this pandemic. Therefore the Indonesian government implemented a social safety net program. This program aims to improve the standard of living of families or individuals who are vulnerable to poverty and are manifested in social assistance. However, the reality on the ground both in the City of Surabaya and Gresik Regency is that there are problems. Obstacles that exist include procedural complexity, limited human resources, confusion of data on aid recipients and less targeted assistance.

\section{REFERENCES}

Bayu, D. J. (2020, A. 14), Jokowi: Pertumbuhan Ekonomi akan Turun Cukup Tajam akibat Corona Katadata.co.id.

Ducharme, J. (2020, M. 11), The WHO Just Declared Coronavirus COVID-19 a Pandemic. TIME.

Governments are still struggling to get ahead of the coronavirus. (2020, M. 17), The Economist.

Kementrian, P., 2014. Perlindungan sosial di Indonesia: Tantangan dan arah ke depan. Jakarta: BAPPENAS RI. 
Paitoonpong, S., Abe, S. \& Puopongsakorn, N., 2008. The meaning of "social safety nets." Journal of Asian Economics, 19(5-6), pp. 467-473.

Suryahadi, A., Al Izzati, R., \& Suryadarma, D., 2020. The Impact of COVID-19 Outbreak on Poverty: An Estimation for Indonesia, Draft. The SMERU Research Institute.

World Bank, The State of Social Safety Nets 2018. 2018. Available at: https://openknowledge.worldbank.org/ handle/10986/29115 License: CC BY 3.0 IGO. 